\title{
The effects of MOTILIPERM on cisplatin induced testicular toxicity in Sprague-Dawley rats
}

Kiran Kumar Soni', Li Tao Zhang ${ }^{1}$, Jae Hyung You', Sung Won Lee ${ }^{3}$, Chul Young Kim, Wan Shou Cui ${ }^{5}$, Han Jung Chae ${ }^{6}$, Hye Kyung Kim ${ }^{1}$ and Jong Kwan Park ${ }^{1,2^{*}}$

\begin{abstract}
Background: Cisplatin causes male infertility but the exact mechanism have not been clarified, yet. MOTILIPERM has been implicated in alleviation of infertility in Sprague-Dawley rats caused by cisplatin. We evaluated recovery effect of MOTILIPERM on cisplatin (CIS)-induced testicular toxicity in Sprague-Dawley rats.

Methods: Five groups were included. The groups are control (CTR), CTR + MOTILIPERM $200 \mathrm{mg} / \mathrm{kg} /$ day per oral, CIS $10 \mathrm{mg} / \mathrm{kg}$ i.V., CIS $10 \mathrm{mg} / \mathrm{kg}$ + MOTILIPERM $100 \mathrm{mg} / \mathrm{kg} /$ day, CIS $10 \mathrm{mg} / \mathrm{kg}$ + MOTILIPERM 200 mg/kg/day. CIS 10 mg/ $\mathrm{kg}$ i.v. single dose was given before $100 \mathrm{mg} / \mathrm{kg}$, or $200 \mathrm{mg} / \mathrm{kg}$ MOTILIPERM per oral daily for 28 days. Body and genital organs weight, epididymis sperm count, sperm motility, sperm apoptosis, testosterone level, MDA of testis tissue, spermatogenic cell density, and Johnsen's score were evaluated. Steroidogenic acute regulatory (StAR) protein, and Glucose-regulated protein-78 (GRP-78), phosphorylated Inositol-Requiring Transmembrane Kinase/Endoribonuclease 1 (IRE1) and phosphorylated c-jun-N-terminal kinase ( $p-J N K$ ) were quantitated by western blot to show its signaling pathway.

Results: The body weight was decreased significantly in CIS $10 \mathrm{mg} / \mathrm{kg}$, CIS $10 \mathrm{mg} / \mathrm{kg}+$ MOTILIPERM $100 \mathrm{mg} / \mathrm{kg} /$ day, CIS $10 \mathrm{mg} / \mathrm{kg}+$ MOTILIPERM $200 \mathrm{mg} / \mathrm{kg} /$ day compared with CTR $(p<0.001)$ however, it was increased in CIS $10 \mathrm{mg} /$ $\mathrm{kg}+$ MOTILIPERM $100 \mathrm{mg} / \mathrm{kg} / \mathrm{day}$, CIS $10 \mathrm{mg} / \mathrm{kg}+$ MOTILIPERM $200 \mathrm{mg} / \mathrm{kg} /$ day compared with CIS $10 \mathrm{mg} / \mathrm{kg}$. The decreased weight of epididymis and prostate were increased significantly in CIS 10 mg/kg + MOTILIPERM 100 mg/kg/ day compared with CIS $10 \mathrm{mg} / \mathrm{kg}$. Sperm count, sperm motility, sperm apoptosis, MDA of testis tissue, spermatogenic cell density, Johnsen's score, and total testosterone were also significantly improved by MOTILIPERM treatment. The levels of decreased StAR protein was significantly improved by MOTILIPERM administration, increased GRP-78 protein p-IRE1and p-JNK was also significantly decreased with MOTILIPREM treatment.
\end{abstract}

Conclusion: The MOTILIPERM could be an effective medicine to reduce the toxic effect caused ER stress by CIS in the testis.

Keywords: Cispaltin (CIS), MOTILIPERM, Spermatogenic cell denity, Steroidogenic acute regulatory (StAR) protein, Glucose-regulated protein-78 (GRP-78), Phosphorylated inositol-requiring transmembrane kinase/endoribonuclease 1 (IRE1), Phosphorylated c-jun-N-terminal kinase (p-JNK)

\footnotetext{
*Correspondence: rain@chonbuk.ac.kr

${ }^{2}$ Biomedical Research Institute and Clinical Trial Center for Medical

Devices of Chonbuk National University Hospital, Jeonju 561-712,

Republic of Korea

Full list of author information is available at the end of the article
} 


\section{Background}

Cis-diamminedichloroplatinum (II) (cisplatin or cisplatinum, CIS), an antineoplastic drug made in the end of the 19th century, around the peculiar atomic configuration of platinum and was described by the Italian chemist Michele Peyrone [1, 2]. CIS has been used worldwide for treatment of other solid neoplasms, including head and neck, lung, colorectal, hematologic, and ovarian cancers [3, 5]. In 1978 the US Food and Drug Administration (FDA) approved the use of CIS for use in testicular and bladder cancer patients [4].

Effects of CIS treatment on testicular function have been noted in human [6] and other animal models [7, 8]. Animals administered CIS develop severe testicular damage characterized by germ cell apoptosis, Leydig cell dysfunction and testicular steroidogenic disorder leading to infertility. Spermatogenesis is affected by CIS by inhibiting nucleic acid synthesis of germ cells [10]. CIS also inhibit testosterone production by damage of Leydig cells [11].

CIS forms covalent adduct with the cellular DNA molecules and terminate the vital processes like replication and transcription and induce apoptosis [12]. The molecular mechanism by which CIS causes reproductive toxicity and germ-cell apoptosis remains to be elucidated [13, 14].

Alternative methods therefore different herbal medicines like Zingiber officinale and Hibiscus sabdariffa, Curcuma longa, Ginkgo biloba or other agents like melatonin, amifostine are used to improve the infertility caused by CIS $[8,14,25,27,30]$.

Cuscuta chinensis, a Chinese Dodder is a parasitic plant. It is commonly used in traditional medicine. It is often used to improve sexual potency [16]. Total flavones from Cuscuta chinensis seeds can increase the testosterone level in the testicle [17]. Allium cepa has antioxidative and androgenic effects in rats that promote spermatogenesis cycle [19,21, 22]. Morinda officinalis is also used to improve the sperm motility [18]. Usually one or the mixture of two herbal medicines are used to treat the testicular toxicity, but we have selected three different herbal medicines to improve the male fertility who are treated with CIS. We used this mixture of three to clarify whether they can improve the CIS inducing male infertility.

\section{Methods}

\section{Animals, chemicals, experiment protocol}

The study was approved by the Ethical Committee of Chonbuk National University followed Basel Declaration. Sexually mature male SD rats weighing 250-300 gm and 9-10 weeks of age were used. The rats were randomly divided into five groups containing 10 rats each, except for the control group with 6 rats. The rats were fed standard rat chow prepared by Feedlab (Guri, Gyeonggi, South Korea) and had access to water. They were maintained in the animal facility under constant environmental conditions (room temperature $20 \pm 2{ }^{\circ} \mathrm{C}$, relative humidity $50 \pm 10 \%$, and 12-hour light-dark cycle).

CIS was purchased from Wako Pure Chemical Industries, Ltd. (Doshomachi, Osaka, Japan). The five groups were control (CTR) group $(n=6)$, CTR + MOTILIPERM $200 \mathrm{mg} / \mathrm{kg}$ per oral (p.o.) (CTR + M 200) group $(n=9)$, CIS $10 \mathrm{mg} / \mathrm{kg}$ intravenous (i.v.) (CIS) group $(n=8)$, CIS $10 \mathrm{mg} / \mathrm{kg}$ i.v. + MOTILIPERM $100 \mathrm{mg} / \mathrm{kg} /$ day p.o. group (CIS + M 100) group $(n=10)$, and CIS $10 \mathrm{mg} / \mathrm{kg}$ i.v. + MOTILIPERM $200 \mathrm{mg} / \mathrm{kg} /$ day p.o. (CIS + M 200) group $(n=7)$. The remaining rats died as we had taken 10 rats in each group, except the control group. All rats were sacrificed after 28 days. CIS $10 \mathrm{mg} / \mathrm{kg}$ body weight mixed in normal saline was given i.v. by the tail vein; this group was sacrificed 7 days after the CIS injection, since we have previously demonstrated the high mortality of rats treated with CIS for more than 7 days. The recovery group that received the CIS was given MOTILIPERM (100 or/and 200) $\mathrm{mg} / \mathrm{kg} /$ day p.o. for 28 days beginning the day following CIS administration. Doses of MOTILIPERM were selected based on previous experiments in our laboratory. We used a 28-day MOTILIPERM treatment period because the normal spermatogenesis period of rats is 12.9 days [9].

\section{Plant material}

MOTILIPERM is currently under development by the Dong-A Pharmaceutical Company (Kyoungi, South Korea) for the treatment of infertility. It was mixed in normal saline. It included Morinda officinalis, Cuscuta chinensis and Allium cepa (100 or $200 \mathrm{mg} / \mathrm{kg} /$ day) was given orally for 28 days.

\section{Extraction and fractionation of MOTILIPERM}

MOTILIPERM was prepared the mixtures of three medicinal herbs. Each herb was ground and extracted three times with ethanol under reflux for $3 \mathrm{~h}$ at $70-80{ }^{\circ} \mathrm{C}$. The combined filtrate was concentrated by rotary evaporator and freeze dried, and stored at $-20{ }^{\circ} \mathrm{C}$ until required. The quality of MOTILIPERM was confirmed by its principal constituents using high-performance liquid chromatography (HPLC). Twenty milligrams of MOTILIPERM was dissolved in $30 \mathrm{mLmethanol} \mathrm{and} \mathrm{fil-}$ tered through a $0.45 \mu \mathrm{M}$ membrane filter. Ten microliters of the filtrate was injected into the HPLC system for analysis. Each peak of MOTILIPERM in the HPLC profile was identified by comparison with the retention times and UV spectra of standard compounds. An Agilent 1200 HPLC system with an INNO column C18 $(4.6 \times 250 \mathrm{~mm}$, YoungJin Biochrom, Seoul, South Korea) was used at a 
flow-rate of $1.0 \mathrm{~mL} / \mathrm{min}$ at $40{ }^{\circ} \mathrm{C}$. The mobile phase consisted of acetonitrile containing $0.1 \%$ trifluoroacetic acid (solvent A) and water containing $0.1 \%$ trifluoroacetic acid (solvent B). A linear gradient system consisted of 0-0 \% A for $0-10 \mathrm{~min}, 0-30 \% \mathrm{~A}$ for $10-40 \mathrm{~min}, 30-50 \% \mathrm{~A}$ for $40-50 \mathrm{~min}, 50-100 \% \mathrm{~A}$ for $50-60 \mathrm{~min}$ and $100 \% \mathrm{~A}$ for 60-70 min. The chromatographic profile of the effluents was recorded at 240 and $254 \mathrm{~nm}$ with a spectrum ranging from 210 to $450 \mathrm{~nm}$. The HPLC profile of MOTILIPERM and its identified compounds are shown in Fig. 1.

\section{Samples collection}

The rats were sacrificed using a mixture of Ketamin $(100 \mathrm{mg} / \mathrm{mL})$ and $2 \%$ rumpun $(20 \mathrm{mg} / \mathrm{mL})$.

\section{Sperm count and motility}

The epididymis was minced and suspended in normal saline at $37{ }^{\circ} \mathrm{C}$ for $5 \mathrm{~min}$. The sperm suspension was placed on a sperm-counting chamber (SEFI-Medical Instruments, Haifa, Israel) with a pipettor. The chamber was warmed to $37{ }^{\circ} \mathrm{C}$ before sperm counts and motility were assessed. The total sperm count was calculated using two or three drops of the specimen to increase the reliability of count determination. Sperm heads were counted in 10 squares. The recorded sperm count represents the concentration of sperm as millions of sperm per $\mathrm{ml}$. The average value was reported. The sperm were counted using the $20 \mathrm{X}$ magnification objective on the light microscope.

\section{Sperm apoptosis}

The number of apoptotic sperms was analyzed by flow cytometry using a Gallios ${ }^{\mathrm{TM}}$ device (Beckman Coulter, Brea, CA, USA). Propidium iodide was purchased from BD Pharmigen (San Diego, CA, USA). Five microlitre of semen sample was taken in an Eppendorf tube, $100 \mu \mathrm{L}$ binding buffer was added, $5 \mu \mathrm{L}$ propidium iodide was added, and the mixture was incubated at room temperature in dark for $20 \mathrm{~min}$. Binding buffer $(400 \mu \mathrm{L})$ was added and apoptosis was measured within an hour.

\section{Biochemistry}

Blood was collected from rats' vena cava. For testosterone estimation, $10 \mu \mathrm{L}$ heparin was added in $1 \mathrm{~mL}$ blood and was centrifuged at $3500 \mathrm{~g}$ for $10 \mathrm{~min}$. Plasma was transferred to a $5 \mathrm{~mL}$ tube and sealed with the paraffin film. All the samples were sent to the hospital laboratory.

\section{Malondialdehyde (MDA)}

Malondialdehyde is a marker for oxidative stress. Homogenized testis tissue was used for MDA analysis. MDA analysis is based on its reaction with thiobarbituric acid to form a pink complex with absorption maximum at $535 \mathrm{~nm}$ [13].

\section{Histology}

For histological estimations, small pieces of testis were fixed in the formalin and stained with hematoxylin and eosin. Sections were examined by light microscopy for spermatogenic cell density measurements. Spermatogenic cell density was determined by measuring the thickness of the germinal cell layer and the diameter of the seminiferous tubules.

Seminiferous tubules were graded by Johnsen's scoring. In this system of classification, seminiferous tubules are assessed according to the presence of spermatogenic cells and each is given a score from 1 to 10 . Complete spermatogenesis with many spermatozoa present is evaluated as score 10. The detailed score histological criteria [28] are: Score 1: No seminiferous epithelium; Score 2: No germinal cells, Sertoli cells only; Score 3: Spermatogonia only; Score 4: No spermatozoa or spermatids, few spermatocytes; Score 5: No spermatozoa or spermatids, many spermatocytes; Score 6: No spermatozoa, no late spermatids, few early spermatids; Score 7: No spermatozoa, no late spermatids, many early spermatids; Score 8: Less than five spermatozoa per tubule, few late spermatids; Score 9: Slightly impaired spermatogenesis, many late spermatids, disorganized epithelium.; and Score 10: Full spermatogenesis.

\section{Western blot}

Glucose-regulated protein-78 (GRP-78), phosphorylated Inositol-Requiring Transmembrane Kinase/Endoribonuclease 1 (IRE1), total IRE1, phosphorylated c-jun-Nterminal kinase (p-JNK) and total JNK measurements in testis tissue were conducted with obtained tissue that had been washed with cold phosphate buffered saline (PBS). Lysis buffer with protease inhibitor was added to tissue, cordless motor pellet pestles was used to pestle and centrifuge at $12,000 \mathrm{rpm}$ for $30 \mathrm{~min}$ at $4{ }^{\circ} \mathrm{C}$.

For StAR protein, crude mitochondrial preparation was acquired as previously described [29]. Testis tissue was thoroughly washed in $2 \mathrm{~mL}$ of sucrose buffer (0.25 $\mathrm{M}$ sucrose, $10 \mathrm{mM}$ tris, $0.1 \mathrm{mM}$ EDTA and $\mathrm{pH} 7.4$ ) and the homogenate centrifuged at $600 \mathrm{rpm}$ for $15 \mathrm{~min}$. The cloudy supernatant, containing the mitochondria was removed and transferred to another tube which was then centrifuged at 12,000 rpm for $15 \mathrm{~min}$. The resulting mitochondrial pellet was washed in sucrose buffer and recentrifuged at 12,000 rpm for $15 \mathrm{~min}$. The pellet was again re-suspended in sucrose buffer and the protein content determined by the method of Bradford for both the lysates. 


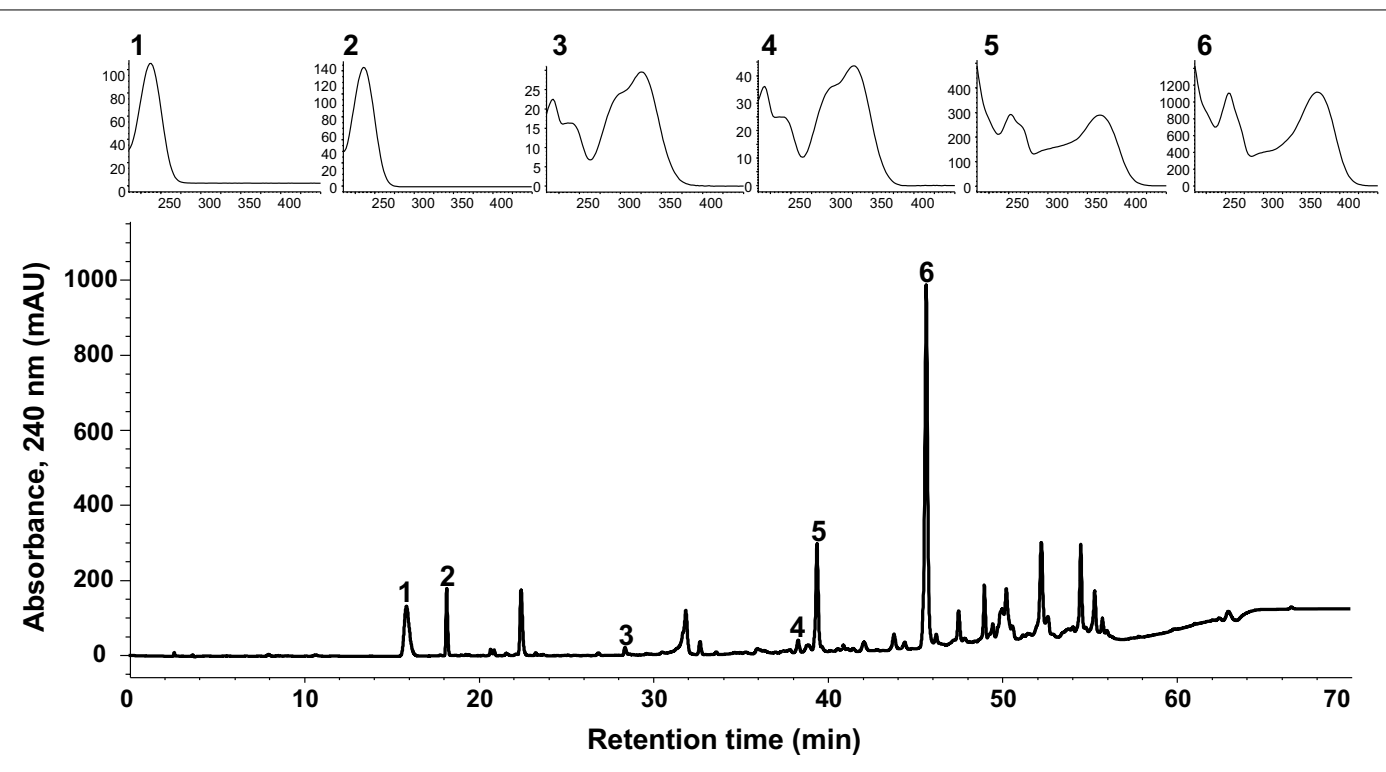<smiles>O=C(O)C1=CO[C@@H](OCl)C2C1C=C[C@@]2(O)CO</smiles><smiles>CC(=O)O[C@H]1OC=C(C(=O)O)C2C(O)=C[C@](O)(CO)[C@@H]21</smiles>

Monotropein (1) deacetyl asperulosidic acid (2)<smiles>O=C(/C=C/c1ccc(O)c(O)c1)O[C@H]1C[C@@](O)(C(=O)O)C[C@H](O)C1O</smiles>

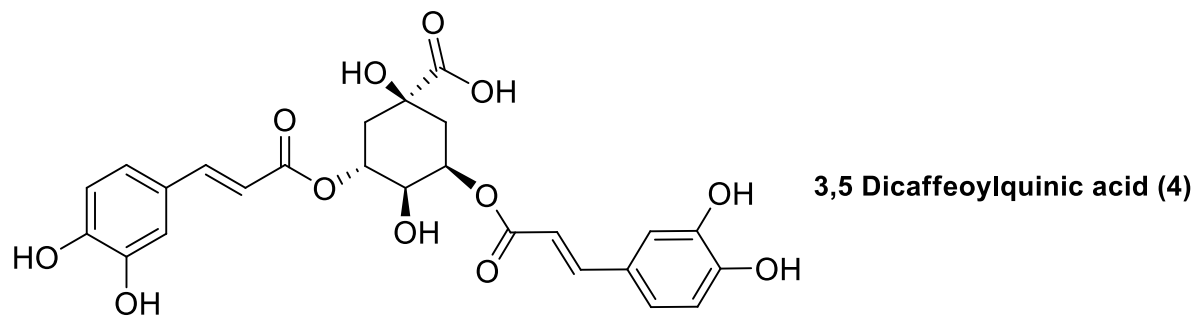<smiles>[R]Oc1ccc(C2=C(O)C(=O)c3c(O)cc(O)cc3C2)cc1O</smiles> 
(See figure on previous page.)

Fig. 1 HPLC chromatogram of MOTILIPERM and ultraviolet spectra of major marker components from each herbal ingredients. Monotropein (1) and deacetyl asperulosidic acid (2) from the Morinda officinalis; Chlorogenic acid (3) and 3,5-dicaffeoylquinic acid (4) from the Cuscuta japonica; quercetin 4'-glcoside (5) and quercetin (6) from the Allium cepa. Each peak of MOTILIPERM in the HPLC chromatogram was identified by comparison with the retention times and UV spectra of standard compounds

The samples were run on $10 \%$ sodium dodecyl sulfate (SDS) gel, transferred on polyvinylidene fluoride (PVDF) membrane by trans-blot ${ }^{\circledR}$ SD semi-dry electrophoretic transfer cell (Bio-Rad, Hercules, CA, USA). After transfer, the membrane was blocked by $10 \%$ Bovine serum albumin (BSA) for an hour and incubated with phosphorylated antibodies p-IRE1(Abcam Cambridge, MA USA), p-JNK (Santa Cruz Biotechnology, Dallas, TX, USA) but non-fat $10 \%$ milk was used for non-phosphorylated antibodies GRP-78, IRE1, and JNK (Santa Cruz Biotechnology, Dallas, TX, USA) for testis tissue. StAR protein (Cell Signaling Technology, Beverly, MA, USA) for mitochondrial extracts with a $1: 1000$ dilution overnight at $4{ }^{\circ} \mathrm{C}$. The membrane was washed with Tris buffered saline Tween (TBST) three times prior to the addition of 1:5000 dilution of secondary antibody for $1 \mathrm{~h}$. The membrane was washed three times with TBST and processed using enhanced chemiluminescence substrate.

\section{Statistical analysis}

Data are expressed as mean $\pm \mathrm{SD}$. The statistical analysis was carried out using SigmaPlot 12.0 (Systat Software, San Jose, CA, USA). $P<0.001$ was considered statistically significant.

\section{Results}

Effect of weights of body, testis, epididymis, and prostate The weights of body in CIS, CIS + M 100, and CIS + M 200 groups were significantly decreased compared with the CTR group. Body weight significantly increased in CIS + M 100, and CIS + M 200 groups compared with CIS group, and in CIS + M 100 compared with CTR + M
200 group. Testis weight had no statistical significance. Epididymis weight in CIS group was significantly decreased compared with CTR group, and in CIS + M 100 compared with CTR + M 200 and CIS groups. There was a significant decrease in prostate weight in CIS, CIS + M 100, and CIS + M 200 groups compared with CTR group, and in CIS + M 200 group compared with CIS group (Table 1).

\section{Effect on sperm count}

The sperm count in CIS group was significantly decreased compared with CTR + M 200 group (Table 2).

\section{Effect on sperm motility}

There was significant decrease sperm motility in CIS, CIS + M 100, and CIS + M 200 groups compared with CTR group, and in CIS + M 100 group compared with CTR + M 200 group (Table 2).

\section{Effect on sperm apoptosis}

There was significant increase apoptosis in CIS group compared with CTR group, and in CIS, CIS + M 100, and CIS + M 200 groups compared with CTR + M 200 group. There was significantly decreased apoptosis in CIS + M 100 and CIS + M 200 groups compared with CIS group (Table 2).

\section{Effect on MDA}

There was significant increase in MDA level in CIS, CIS + M 100 and CIS + M 200 groups compared with CTR and CTR + M 200 groups. There was also significant decrease of MDA level in CIS + M 100 and CIS + M 200 group compared with CIS group (Fig. 2).

Table 1 The effect of the MOTILIPERM on body, testicular, epididymis and prostate weights

\begin{tabular}{lcccc}
\hline & CTR & CTR + M 200 & \multicolumn{2}{c}{ CIS groups } \\
\cline { 3 - 5 } & & & CIS & CIS + M 100 \\
\hline Body Wt (gm) & $419 \pm 37.22$ & $349.6 \pm 13.79$ & $338 \pm 16.19^{* *}$ & $386.3 \pm 16.15^{*,+1, \# \#}$ \\
Testis Wt (gm) & $2.05 \pm 0.13$ & $1.99 \pm 0.10$ & $1.95 \pm .014$ & $1.97 \pm 0.13$ \\
Epididymis Wt (gm) & $0.70 \pm 0.02$ & $0.60 \pm 0.05$ & $0.59 \pm 0.05^{* *}$ & $0.66 \pm 0.05^{\dagger, \#}$ \\
Prostate Wt (gm) & $1.48 \pm 0.23$ & $1.14 \pm 0.18$ & $1.18 \pm 0.19^{*}$ & $1.96 \pm .014$ \\
\hline
\end{tabular}

Data are presented in mean \pm SD

Wt weight; CTR control; CTR + M 200 CTR + MOTILIPERM 200 mg/kg/day; CIS cisplatin $10 \mathrm{mg} / \mathrm{kg}$ intravenous (i.v.); CIS + M 100 CIS $10 \mathrm{mg} / \mathrm{kg}$, i.v. + MOTILIPERM $100 \mathrm{mg} / \mathrm{kg} / \mathrm{day} ;$ CIS + M 200 CIS $10 \mathrm{mg} / \mathrm{kg}$, i.v. + MOTILIPERM $200 \mathrm{mg} / \mathrm{kg} /$ day. M MOTILIPERM

${ }^{*} p<0.05$ vs CTR group, ${ }^{\dagger} p<0.05$ vs CTR + M 200 group, ${ }^{\#} p<0.05$ vs CIS group, ${ }^{* *} p<0.001$ vs CTR group, ${ }^{+\dagger} p<0.001$ vs CTR M 200 group $2,{ }^{\# \#} p<0.001$ vs CIS group 
Table 2 The effect of the MOTILIPERM on epididymis sperm count, motility and apoptosis

\begin{tabular}{|c|c|c|c|c|c|}
\hline & \multirow[t]{2}{*}{ CTR } & \multirow[t]{2}{*}{ CTR + M 200} & \multicolumn{3}{|l|}{ CIS groups } \\
\hline & & & CIS & CIS + M 100 & CIS + M 200 \\
\hline Sperm count $\left(10^{6}\right)$ & $25.17 \pm 5.95$ & $28.83 \pm 6.10$ & $22.06 \pm 8.78^{\dagger}$ & $25.40 \pm 4.65$ & $28.21 \pm 4.46$ \\
\hline Sperm motility (\%) & $33.29 \pm 19.01$ & $29.13 \pm 15.83$ & $17.56 \pm 15.16^{*}$ & $17.87 \pm 8.47^{*},+$ & $19.86 \pm 12.91^{*}$ \\
\hline Sperm apoptosis (\%) & $17.38 \pm 1.85$ & $8.03 \pm 2.96$ & $24.68 \pm 4.22^{*},+\dagger$ & $19.97 \pm 4.68^{\dagger+, \#}$ & $19.90 \pm 3.56^{t+, \#}$ \\
\hline
\end{tabular}

Data are presented in mean $\pm S D$

CTR control; CTR + M 200 CTR + MOTILIPERM 200 mg/kg/day; CIS cisplatin 10 mg/kg intravenous (i.v.); CIS + M 100 CIS 10 mg/kg, i.v. + MOTILIPERM 100 mg/kg/day; CIS + M 200 CIS $10 \mathrm{mg} / \mathrm{kg}$, i.v. + MOTILIPERM $200 \mathrm{mg} / \mathrm{kg} /$ day. M MOTILIPERM

${ }^{*} p<0.05$ vs CTR group, ${ }^{\dagger} p<0.05$ vs CTR + M 200 group $2,{ }^{*} p<0.05$ vs CIS group, ${ }^{\text {t+ }} p<0.001$ vs CTR + M 200 group

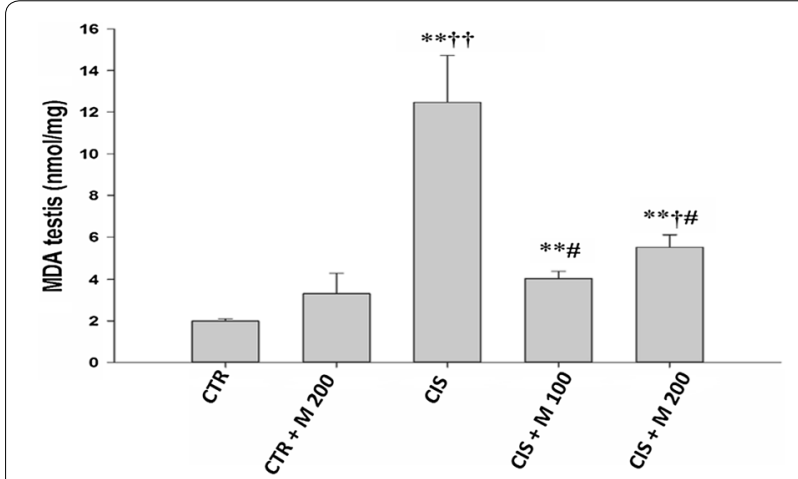

Fig. 2 Evaluation of MDA for each group. Data are presented in mean \pm SD. ${ }^{\dagger} p<0.05$ vs CTR + M 200 group, ${ }^{\#} p<0.05$ vs CIS group, ${ }^{* *} p<0.001$ vs CTR group, ${ }^{\dagger+} p<0.001$ vs CTR + M 200 group

\section{Effect on plasma testosterone and StAR protein}

There was a significant decrease of testosterone level in CIS, CIS + M 100, and CIS + M 200 groups compared with CTR + M 200 group (Fig. 3a; Table 3). There was significant increase of testosterone in CIS + M 100 group compared with CIS group. Significantly decreased StAR protein level was evident in CIS group compared with CTR and CTR + M 200 groups. There were no significant changes in CIS + M 100 and CIS + M 200 groups compared with CIS group (Fig. 3b, c).

\section{Histopathological effects}

Testis tissue showed normal arrangement of the germinal cells, Sertoli cells, and Leydig cells without histopathological lesions in CTR and CTR + M 200 groups.
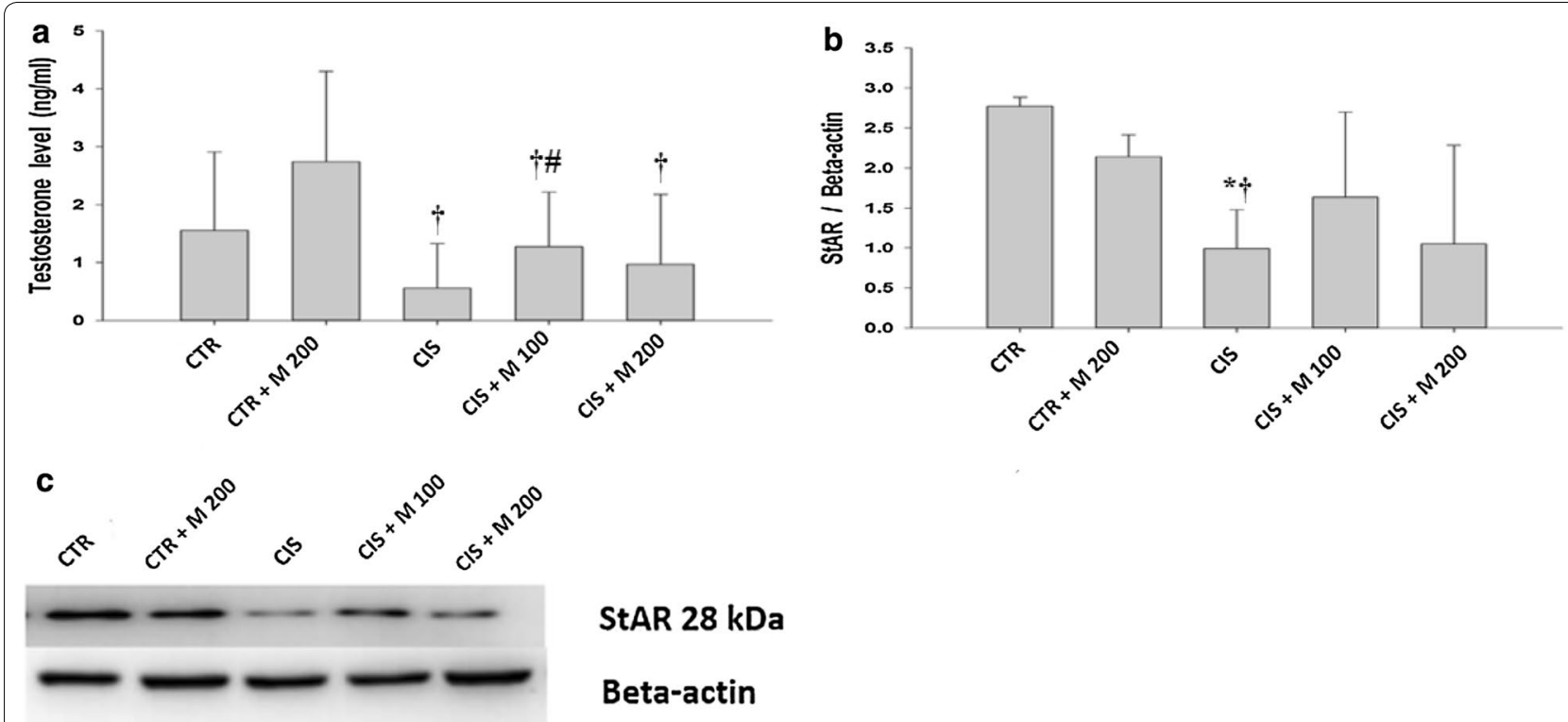

Fig. 3 Effects of cisplatin (CIS) and MOTILIPERM on total testosterone and StAR protein by Western blot. a Total testosterone level. b StAR protein. c Western blotting of StAR protein for each group. Data are presented in mean \pm SD. CTR control; CTR + M 200 CTR + MOTILIPERM $200 \mathrm{mg} / \mathrm{kg} / \mathrm{day}$; CIS cisplatin $10 \mathrm{mg} / \mathrm{kg}$ i intravenous (i.v.); CIS + M 100 CIS $10 \mathrm{mg} / \mathrm{kg}$, i.v. + MOTILIPERM $100 \mathrm{mg} / \mathrm{kg} / \mathrm{day}$; CIS + M 200 CIS $10 \mathrm{mg} / \mathrm{kg}$, i.V. + MOTILIPERM 200 mg/kg/day p.o. M MOTILIPERM. ${ }^{*} p<0.05$ vs CTR group, ${ }^{\dagger} p<0.05$ vs CTR + M 200 group, ${ }^{\#} p<0.05$ vs CIS group 
Table 3 The effect of the MOTILIPERM on testosterone assay and spermatogenic cell density

\begin{tabular}{llllll}
\hline & CTR & CTR + M 200 & \multicolumn{2}{ll}{ CIS groups } & \\
\cline { 4 - 6 } & & & CIS & CIS + M 100 & CIS + M 200 \\
\hline Testosterone $(\mathrm{ng} / \mathrm{ml})$ & $1.56 \pm 1.35$ & $2.74 \pm 1.56$ & $0.56 \pm 0.78^{+}$ & $1.27 \pm 0.95^{\dagger, \#}$ & $0.96 \pm 1.22^{+}$ \\
Spermatogenic cell density & $0.35 \pm 0.07$ & $0.32 \pm 0.08$ & $0.18 \pm 0.03^{*}$ & $0.269 \pm 0.028$ & $0.26 \pm 0.04$ \\
\hline
\end{tabular}

\section{Data are presented in mean $\pm S D$}

CTR control; CTR + M 200 CTR + MOTILIPERM 200 mg/kg/day; CIS cisplatin 10 mg/kg intravenous (i.v.); CIS + M 100 CIS 10 mg/kg, i.v. + MOTILIPERM 100 mg/kg/day; $\mathrm{CIS}+\mathrm{M} 200 \mathrm{CIS} 10 \mathrm{mg} / \mathrm{kg}$, i.v. + MOTILIPERM $200 \mathrm{mg} / \mathrm{kg} / \mathrm{day}$

* $p<0.05$ vs CTR group, ${ }^{\dagger} p<0.05$ vs CTR + M 200 group, ${ }^{*} p<0.05$ vs CIS group

CIS group showed degeneration and disorganization of germinal cells, Sertoli cells, and Leydig cells. CIS $+\mathrm{M}$ 100 and CIS + M 200 groups showed the degeneration and disorganization of the testis tissue, but less than in CIS group. There was a significant decrease in the spermatogenic cell density in CIS group compared with CTR group (Fig. 4a, b; Table 3). Johnsen's score was significantly decreased in CIS and CIS + M 100 group compared with CTR and CTR + M 200 groups, and it also was significantly increased in CIS + M 200 group compared with CIS group (Fig. 4c).

\section{GRP-78, p-IRE 1 and $p-J N K$}

Significantly increased GRP-78 was evident in CIS and CIS + M 100 groups compared with CTR + M 200 group. CIS + M 100 and CIS + M 200 groups showed significantly decreased GRP-78 compared with CIS group (Fig. 5a, b). p-IRE1 was significantly increased in

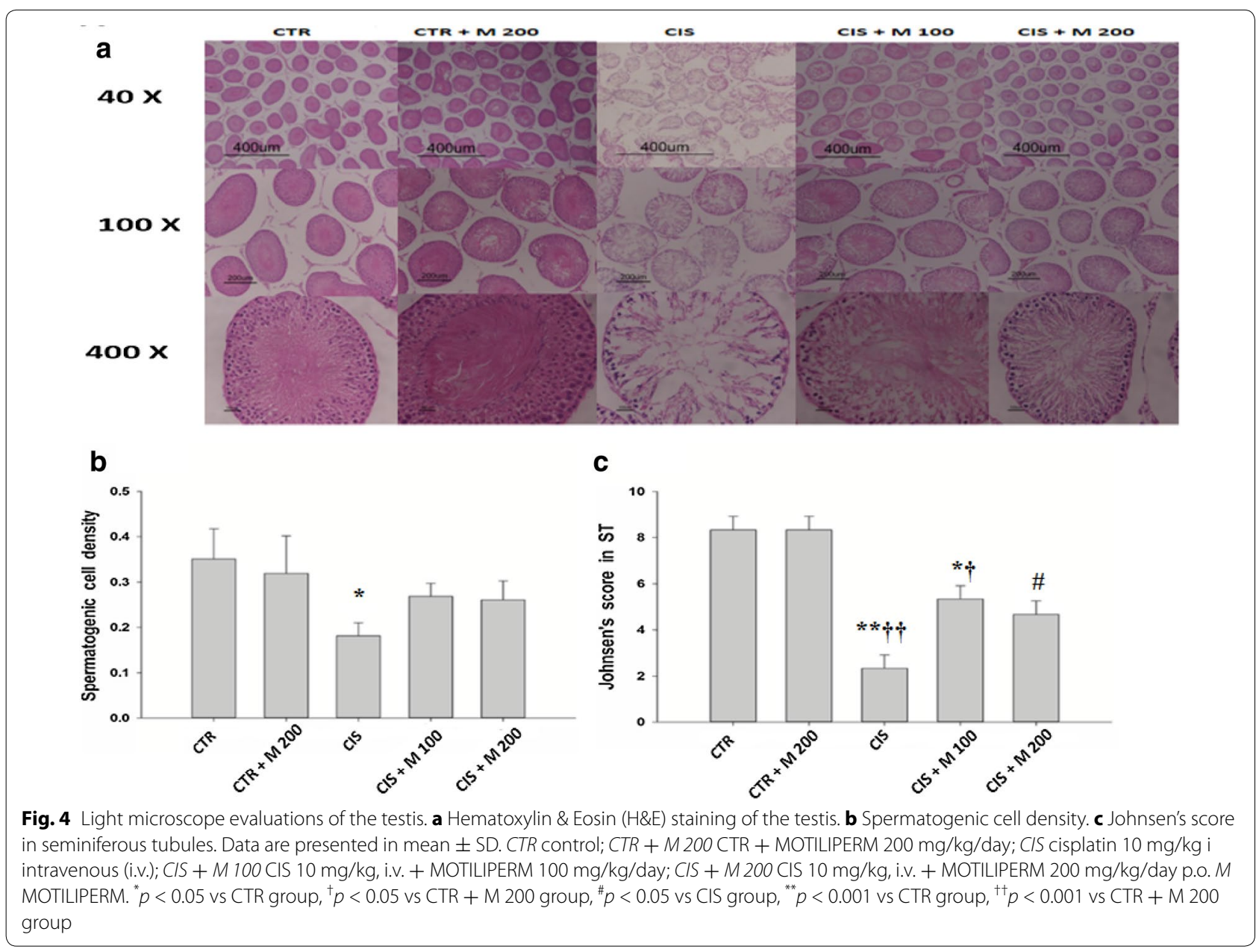




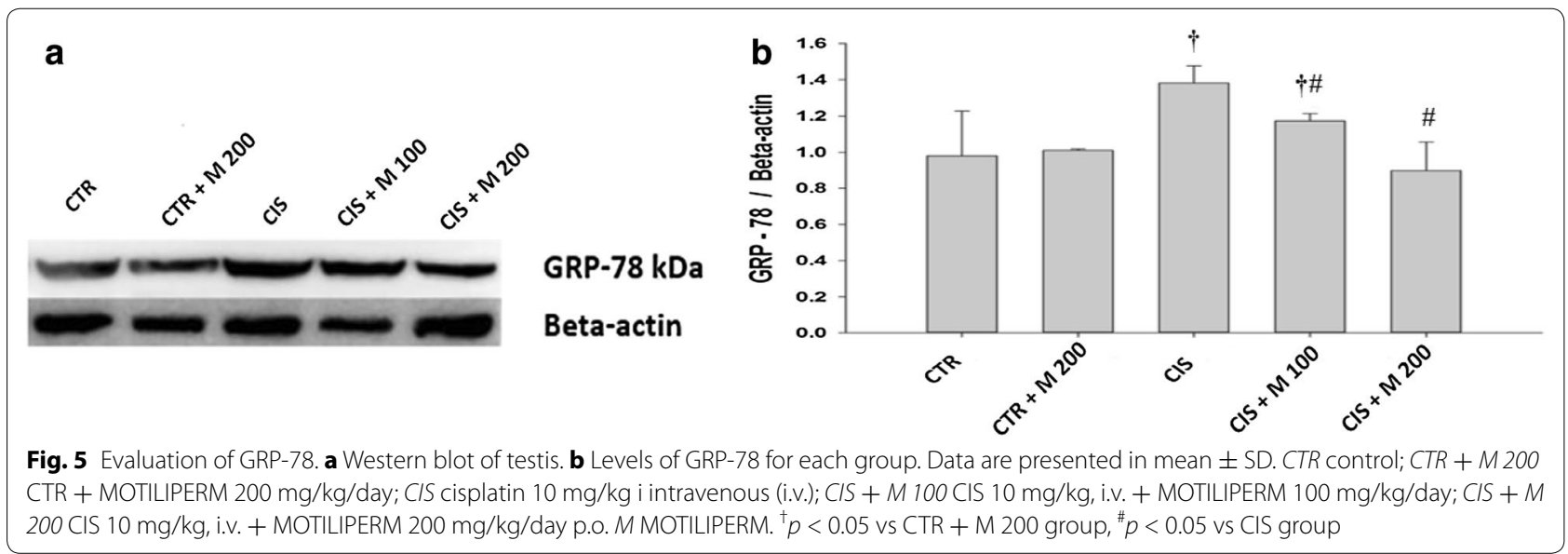

CIS group compared to CTR and CTR + M200 groups (Fig. 6a, b). Significantly increased p-JNK was evident in CIS, CIS + M 100, and CIS + M 200 groups compared with CTR group. CIS and group also showed significantly increased compared with CTR + M 200 group (Fig. 7a, b).

\section{Discussion}

CIS is one of the potent anticancer drugs in the chemotherapy treatment; it induces a testicular disintegration, sperm dysfunction, germ-cell apoptosis, and abnormalities in Leydig cells in rats [7, 23]. CIS has significant decrease in the physical weight, reproductive organ weights, plasma testosterone level and spermatozoa compared with untreated control animals. CIS shows impaired fertility along with alterations on the growth and development of the next generations [26].
Thus, the toxic effects of CIS on the germ cells led for further research either to preserve the fertility in men who are undergoing chemotherapy. Semen preservation for future use has increased the chances of pregnancies. But freezing and thawing of semen can reduce the sperm quality [15].

The studies showed the protective effects of herbal plants extracts against CIS due to the presence of antioxidant effects in the herbal medicine [24]. Peng et al. studied about the effects of Cuscuta chinensis on human sperm motility in vitro function. The results showed that the motility of sperm significantly improved and the function of sperm membrane became more stable after incubation [18]. In young men antioxidants protect DNA from oxidation and damage and improve the sperm quality $[20]$.
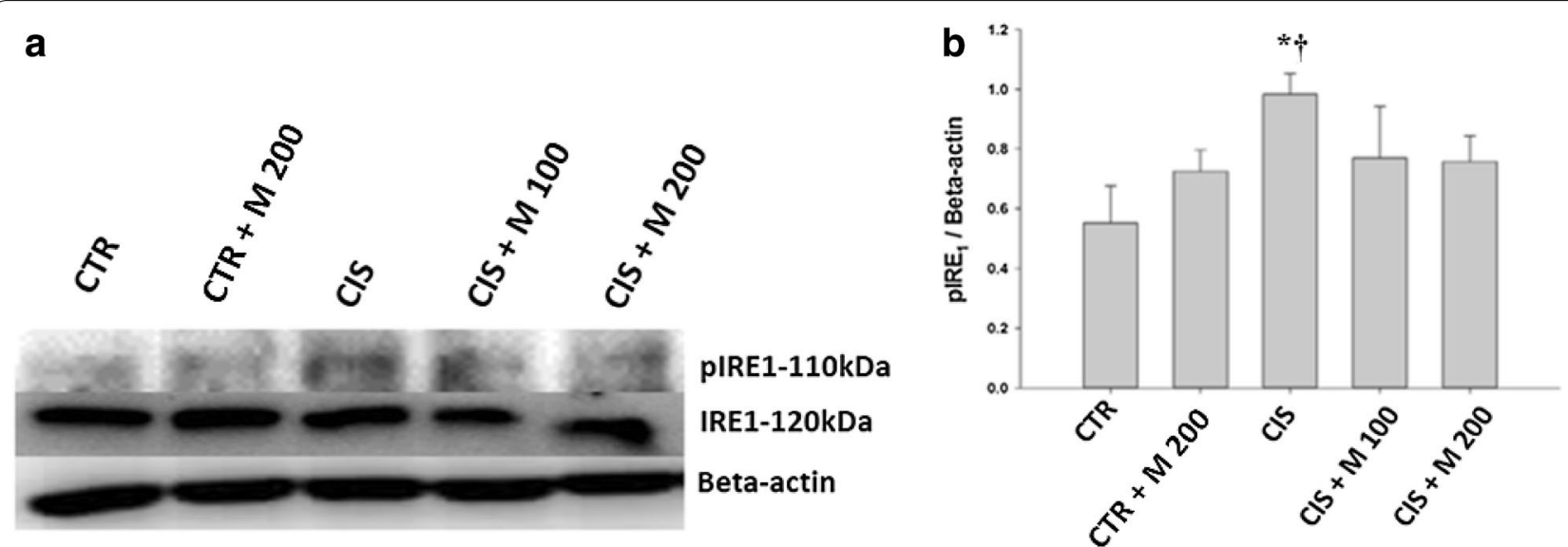

Fig. 6 Evaluation of p-IRE1, IRE1, a Western blot of testis. b Levels of pIRE1 and total IRE1 for each group. Data are presented in mean \pm SD. CTR control; CTR + M 200 CTR + MOTILIPERM $200 \mathrm{mg} / \mathrm{kg} /$ day; CIS cisplatin $10 \mathrm{mg} / \mathrm{kg}$ i intravenous (i.v.); CIS + M 100 CIS $10 \mathrm{mg} / \mathrm{kg}$, i.V. + MOTILIPERM $100 \mathrm{mg} / \mathrm{kg} / \mathrm{day} ;$ CIS + M 200 CIS $10 \mathrm{mg} / \mathrm{kg}$, i.v. + MOTILIPERM $200 \mathrm{mg} / \mathrm{kg} /$ day p.O. M MOTILIPERM. ${ }^{*} p<0.005$ vs CTR group, ${ }^{\dagger} p<0.05$ vs CTR + M 200 group 

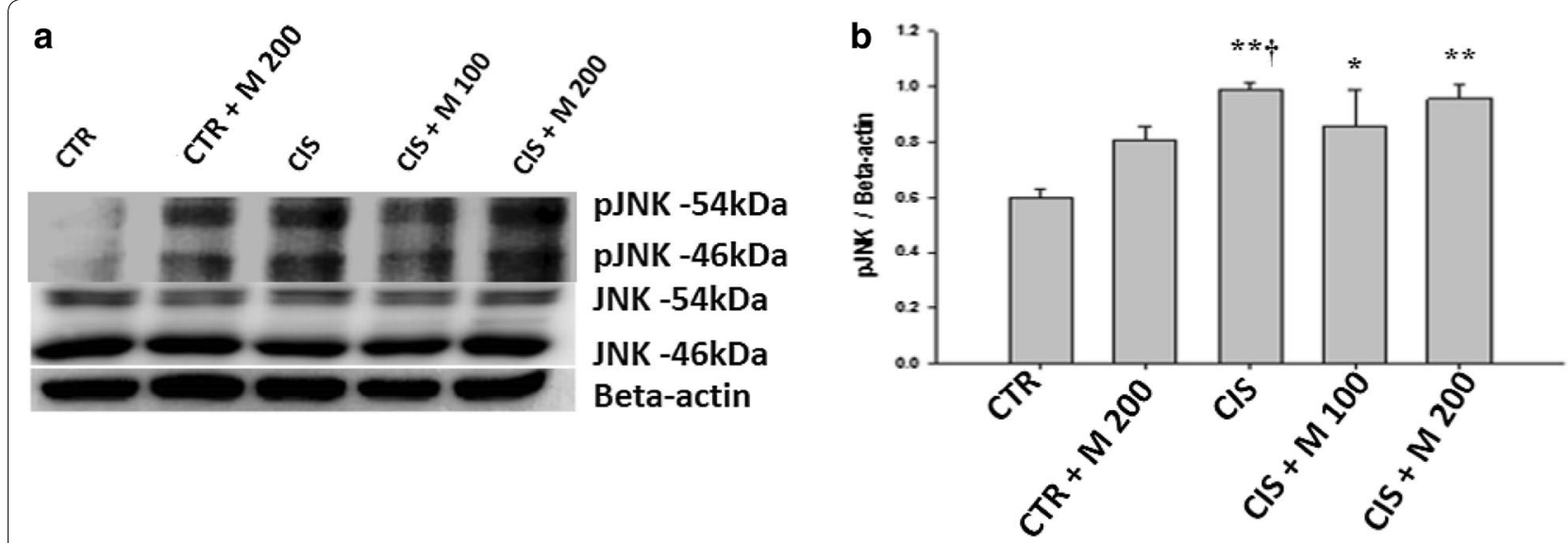

Fig. 7 Evaluation of pJNK and JNK a Western blot of testis. b Levels of pJNK and total JNK for each group. Data are presented in mean \pm SD. CTR control; CTR + M 200 CTR + MOTILIPERM $200 \mathrm{mg} / \mathrm{kg} /$ day; CIS cisplatin $10 \mathrm{mg} / \mathrm{kg}$ i intravenous (i.v.); CIS + M 100 CIS $10 \mathrm{mg} / \mathrm{kg}$, i.V. + MOTILIPERM $100 \mathrm{mg} / \mathrm{kg} /$ day; CIS + M 200 CIS $10 \mathrm{mg} / \mathrm{kg}$, i.v. + MOTILIPERM $200 \mathrm{mg} / \mathrm{kg} /$ day p.o. M MOTILIPERM. ${ }^{*} p<0.05$ vs CTR group, ${ }^{\dagger} p<0.05$ vs CTR + M 200 group, ${ }^{* *} p<0.001$ vs CTR group

CIS damages testicular tissue and reduces sperm production through increasing oxidative stress and inducing apoptosis and upregulations of nuclear factor kappa-lightchain-enhancer of activated B cells (NF-kB), inducible nitric oxide synthase (iNOS), and cyclooxygenase-2 (COX-2), while Ginkgo biloba reduces these oxidative and apoptosis actions of CIS in testis [25]. CIS activate mitogen-activated protein kinases (MAPK), nuclear factorkappa NF-kB and nitric oxide synthase iNOS expression that has role in pathogenesis in rat testis induced by CIS is blocked by antioxidant such as Curcuma longa [30].

Zingiber officinale and Hibiscus sabdariffa have also been reported to prevent CIS related damage in testicular tissue and sperm cells by its antioxidant and anti-inflammatory agents [8]. Besides herbal medicines melatonin decrease malondialdehyde (MDA) and increase glutathione (GSH) levels in several pathological conditions like CIS toxicity [14]. Amifostine partially protect the rat seminiferous epithelium against CIS toxicity [27].

There are three signaling pathways from ER Stress sensors [31], they are Activating Transcription Factor-6 (ATF6), Protein kinase RNA-like endoplasmic reticulum kinase (PERK) and Inositol-Requiring Transmembrane Kinase/Endoribonuclease 1 (IRE1). Prolonged ER stress activates IRE1 and it may interacts with tumor necrosis factor receptor associated factor 2 (TRAF2) [32]. The IRE1-TRAF2 complex may activate (Apoptosis signalregulating kinase) ASK1, also known as MAP kinase kinase, leading to activation of JNK pathway. ER stressinduced activation of the ASK1-JNK pathway may trigger apoptosis (Fig. 8) [33].

In our study we have designed to show CIS administration caused testicular toxicity within a week, which

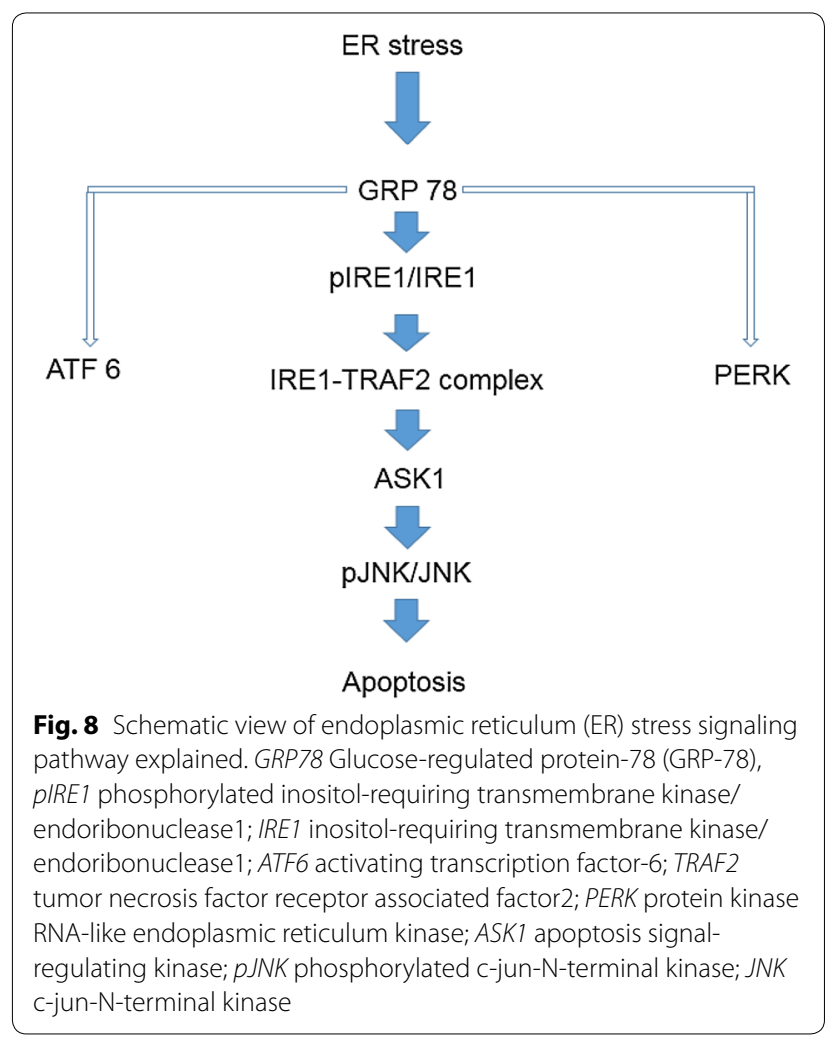

recovers by administration of MOTILIPERM orally in 28 days. MOTILIPERM of different doses offers recovery of apoptotic changes against the CIS. This recovery effect was seen in the sperm cell by the flow cytometry where apoptosis was more in CIS group than MOTILIPERM treated group just after CIS administration. It was 
further accompanied with the restoration of body weight where the testis weight and epididymis weight both were restored but in some part, CIS + M 100 group showed better results than the CIS + M 200 group. The exact mechanism of it is not so clear. Sperm count and sperm motility of the epididymis were also seen to increase compared to the CIS group. MDA level was increased in CIS treated groups.

Total testosterone level was also increased in the recovery group where MOTILIPERM is given just after CIS administration. CIS cause damage of the Leydig cells [11], so the testosterone production is hampered. The StAR protein in the testis tissue showed decreased level in CIS group and recovery groups compared with the CTR, M-200 group in western blot results.

GRP-78, p-IRE1, and p-JNK proteins were increased in CIS, CIS + M 100, and CIS + M 200 groups compared with CTR group and CTR + M 200 groups but it was seen decreased in CIS + M 200 group compared with other groups. When we see the arrangement of the testis tissue we also got the decrease of the germ cells density in the seminiferous tubules in the CIS treated group and the group where $200 \mathrm{mg} / \mathrm{kg} /$ day of MOTILIPERM was given just after the CIS is administered in it, and also the disintegration of the Leydig cells that produces the testosterone.

\section{Conclusions}

This study provides sufficient evidence that CIS has a toxic effect on body and reproductive organs by ER stress in the rat. MOTILIPERM decreased these detriments, and so may be potentially valuable in chemotherapy relating infertility.

\section{Authors' contributions}

KKS, LTZ, BRC, JHY, SWL, CYK, WSC, HJC, HKK, and JKP had full access to all the data in the study and takes responsibility for the integrity of the data and the accuracy of the data analysis. Study concept and design: JKP. Acquisition of data: KKS. Analysis and interpretation of data: LTZ, BRC, HKK, HJC, JKP. Drafting of the manuscript: KKS and JKP. Critical revision of the manuscript of important intellectual content: JKP. Statistical analysis: KKS, YSS. Obtaining funding: JKP. Administrative, technical, or material support: BRC, WSC. Supervison: SWL, CYK, JKP. Others (specify). All authors read and approved the final manuscript.

\begin{abstract}
Author details
${ }^{1}$ Department of Urology, Institute for Medical Sciences, Chonbuk National University of Medical School, Jeonju 561-712, Republic of Korea. ${ }^{2}$ Biomedical Research Institute and Clinical Trial Center for Medical Devices of Chonbuk National University Hospital, Jeonju 561-712, Republic of Korea. ${ }^{3}$ Department of Urology, Samsung Medical Center, Samsung Biomedical Research Institute, Sungkyunkwan University Medical School, Seoul, Republic of Korea. ${ }^{4} \mathrm{Col}-$ lege of Pharmacy, Hangyang University, Ansan 426-791, Republic of Korea. ${ }^{5}$ Andrology Center, Peking University First Hospital, Beijing 100034, China. ${ }^{6}$ Department of Pharmacology, Chonbuk University Medical School, Jeonju, Republic of Korea.
\end{abstract}

\section{Acknowledgements}

The authors thank the members of the Laboratory of Experimental Urology for helpful discussions.

\section{Disclosure}

The authors excluding Jong Kwan Park have nothing to disclose.

\section{Financial disclosure}

Jong Kwan Park certificates that all conflicts of interest, including specific financial interests and relationships and affiliations relevant to the subject matter or materials discussed in the manuscript (e.g., employment/affiliation, grants or funding, consultancies, honoraria, stock ownership or options, expert testimony, royalties, or patents filed, received, or pending), are the following: Jong Kwan Park is a consultant and speaker for and has received unconditional research grants from Dong-A Pharmaceutical Company, Yong-in, Kyoung-gi, Republic of Korea, but the company had no role in the design or conduct of the study; collection, management, analysis, and interpretation of the data; or preparation, review, or approval of the manuscript.

\section{Funding/support and role of the sponsor}

This study was supported by grants from the Korea Healthcare Technology R\&D Project, Ministry for Health, Welfare \& Family Affairs, Republic of Korea (HI14C0018). The Korea Healthcare Technology R\&D Project, Ministry for Health, Welfare \& Family Affairs, Republic of Korea had no role in the design or conduct of the study; collection, management, analysis, and interpretation of the data; or preparation, review, or approval of the manuscript. The content of this article is solely the responsibility of the authors and does not necessarily represent the official views of the Korea Healthcare Technology R\&D Project, Ministry for Health, Welfare \& Family Affairs, Republic of Korea.

Received: 30 August 2015 Accepted: 9 December 2015

Published online: 18 December 2015

\section{References}

1. Peyrone M. Ueber die Einwirkung des Ammoniaks auf Platinchlorür. Ann Chemie Pharm. 1844;51(1):1-29.

2. Burchenal JH, Kalaher K, Dew K, Lokys L. Rationale for development of platinum analogs. Cancer Treat Rep. 1979;63(9-10):1493-8.

3. Lebwohl D, Canetta R. Clinical development of platinum complexes in cancer therapy: an historical perspective and an update. Eur J Cancer. 1998;34(10):1522-34.

4. Kelland $\mathrm{L}$. The resurgence of platinum-based cancer chemotherapy. Nat Rev Cancer. 2007;7(8):573-84.

5. Prestayko AW, D'Aoust JC, Issell BF, Crooke ST. Cisplatin (cis-diamminedichloroplatinum II). Cancer Treat Rev. 1979;6(1):17-39.

6. Boekelheide K. Mechanisms of toxic damage to spermatogenesis. J Natl Cancer Inst Monogr. 2005;34:6-8.

7. Cherry SM, Hunt PA, Hassold TJ. Cisplatin disrupts mammalian spermatogenesis, but does not affect recombination or chromosome segregation. Mutat Res. 2004;564(2):115-1128.

8. Amin A, Hamza A. Effects of ginger and roselle on cisplatininduced reproductive toxicity in rats. Asian J Androl. 2006;8(5):607-12.

9. Franca L, Ogawa T, Avarbock M, Brinster R, Russell L. Germ cell genotype controls cell cycle during spermatogenesis in the rat. Biol Reprod. 1998;59(6):1371-7.

10. Adler ID, El Tarras A. Clastogenic effects of cis-diamminedichloroplatinum II. Induction of chromosomal aberrations in primary spermatocytes and spermatogonial stem cell of mice. Mutat Res. 1990;243(3):173-8.

11. Vawda Al. Effect of testosterone on cisplatin-induced testicular damage. Arch Androl. 1994;32(1):53-7.

12. Johnson SW, Ferry KV, Hamilton TC. Recent insights into platinum drug resistance in cancer. Drug Resist Updat. 1998;1(4):243-54.

13. Amin A, Hamza AA, Kmbal A, Daoud S. Herbal extracts counteract cisplatin-mediated cell death in rat testis. Asian J Androl. 2008;10(2):291-7.

14. Atessahin A, Sahna E, Turk G, Ceribaşi AO, Yilmaz S, Yüce A, et al. Chemoprotective effect of melatonin against cisplatin-induced testicular toxicity in rats. J Pineal Res. 2006;41(1):21-7.

15. Alvarez JG, Storey BT. Evidence for increased lipid peroxidase damage and loss of superoxid dismutase activity as a mode of sublethal cryodamage of humans sperm during cryopreservation. J Androl. 1992;13(3):232-41.

16. Mavlonov GT, Ubaidullaeva KA, Kadryaeva GV, Kuznetsova NN. Cytotoxic components of Cuscuta. Chem Nat Compd. 2008;44(3):409-10. 
17. Yang JX, Wang YL, Bao Y, Guo J. The total flavones from Semen cuscutae reverse the reduction of testosterone level and the expression of androgen receptor gene in kidney-yang deficient mice. J Ethnopharmacol. 2008;119(1):166-71.

18. Peng SJ, Lu RK, Yu LH. Effect of Semen cuacutae, Rhizoma curculiginis, Radix morindae, Officinalis on human spermatozoa's motility and membrane function in vitro. Chinese Journal of integrated traditional and Western Medicine. 1997;17(3):145-7.

19. Khaki A, Fathiazad F, Nouri M, Khaki AA, Khamenehi HJ, Hamadeh M. Evaluation of androgenic activity of allium cepa on spermatogenesis in the rat. Folia Morphol (Warsz). 2009;8(1):45-51.

20. Yang HS, Han DK, Kim JR, Sim JC. Effects of alpha- tocopherol on cadmium-induced toxicity in rat testis and spermatogenesis. J Korean Med Sci. 2006;21(3):445-51.

21. Cummings $\mathrm{JH}$, Bingham SA. Fortnightly review diet and the prevention of cancer. BMJ. 1998;317(7173):1636-40.

22. Endre $L$, Beck F, Prasad A. The role of zinc in human health. J Trace Elem Exp Med. 1990:3:337-75.

23. Meistrich ML, Finch M, Da Cunha MF, Hacker U, Au WW. Damaging effects of fourteen chemotherapeutic drugs on mouse testis cells. Cancer Res. 1982;42(1):122-31.

24. Azu OO, Duru FIO, Osinubi AA, Noronha CC, Elesha SO, Okanlawon AO. Protective agent, Kigelia Africana fruit extract, against cisplatin-induced kidney oxidant injury in Sprague-Dawley rats. Asian J Pharma Clin Res. 2010;3(2):84-8.

25. Amin A, Mahmoud-Ghoneim D, Syam MI, Daoud S. Neural network assessment of herbal protection against chemotherapeutic-induced reproductive toxicity. Theor Biol Med Model. 2012;24(9):1.
26. Sharma RK, Agarwal A. Role of reactive oxygen species in male infertility. Urology. 1996;48(6):835-50.

27. Lirdi LC, Stumpp T, Sasso-Cerri E, Miraglia SM. Amifostine protective effect on cisplatin-treated rat testis. Anat Rec (Hoboken). 2008:291(7):797-808.

28. Yoshida A, Miura K, Shirai M. Evaluation of seminiferous tubule scores obtained through testicular biopsy examinations of nonobstructive azoospermic men. Fertil Steril. 1997;68(3):514-8.

29. Clark BJ, Wells J, King SR, Stocco DM. The purification, cloning, and expression of a novel luteinizing hormone-induced mitochondrial protein in MA-10 mouse Leydig tumor cells-characterization of the steroidogenic acute regulatory protein (StAR). J Biol Chem. 1994;269(45):28314-22.

30. Ilbey YO, Ozbek E, Cekmen M. Protective effect of curcumin in cisplatininduced oxidative injury in rat testis: mitogen-activated protein kinase and nuclear factor-kappa B signaling pathways. Hum Reprod. 2009;24(7):1717-25.

31. Kadowaki $H$, Nishitoh $H$. Signaling Pathways from the Endoplasmic Reticulum and Their Roles in Disease. Genes (Basel). 2013;4(3):306-33.

32. Urano F, Wang X, Bertolotti A, Zhang Y, Chung P, Harding HP, Ron D. Coupling of stress in the ER to activation of jnk protein kinases by transmembrane protein kinase IRE1. Science. 2000;287(5453):664-6.

33. Nishitoh H, Matsuzawa A, Tobiume K, Saegusa K, Takeda K, Inoue K, Hori S, Kakizuka A, Ichijo H. Ask1 is essential for endoplasmic reticulum stress-induced neuronal cell death triggered by expanded polyglutamine repeats. Genes Dev. 2002;16(11):1345-55.

\section{Submit your next manuscript to BioMed Central and we will help you at every step:}

- We accept pre-submission inquiries

- Our selector tool helps you to find the most relevant journal

- We provide round the clock customer support

- Convenient online submission

- Thorough peer review

- Inclusion in PubMed and all major indexing services

- Maximum visibility for your research

Submit your manuscript at www.biomedcentral.com/submit

() Biomed Central 